\title{
Japanese encephalitis in children
}

\author{
Nurhayati Masloman, MD; HS Widarso, MD; W Cicilia, MD
}

$J$

apanese encephalitis is a zoonotic disease caused by Japanese encephalitis virus, attacking domestic animals, mainly pigs and birds. ${ }^{1}$ It is transmitted to humans by mosquito bites, namely Culex tritaeniorhyncus. ${ }^{1,2}$

Japanese encephalitis may occur at any age with a peak incidence in children less than 15 years. ${ }^{2,3}$ Most cases are asymptomatic, and the ratio between asymptomatic and symptomatic cases is $25-1,000: 1 .^{2}$ This disease is endemic in Southeast Asia including Indonesia, occurring throughout the year with higher incidence during rainy season, with as many as 1,000 2,000 new cases reported each year. ${ }^{4}$

Lubis reported 30 cases (25.4\%) of Japanese encephalitis out of 118 suspected cases of viral encephalitis in Jakarta from April 1981 to March 1982. ${ }^{5}$ While Kari et al, reported 55 cases of Japanese encephalitis with an incidence rate of 1:14,000 and mortality rate of $7.27 \%{ }^{6}$

\section{Case Report}

\section{Case 1}

An 11 year and 2 month old boy was admitted to Manado Hospital on November 5, 2002 with seizures and unconsciousness as chief complaints. He had suffered from general tonic-clonic seizures for 5 days, proceeded by high fever, without vomiting or headache. The seizures occurred up to five times a day, each lasting about five minutes. Thereafter, his consciousness deteriorated. There was a pigpen next to his house. His physical examination revealed a normal nutritional status, blood pressure of 120/80 mmHg, pulse of $112 \mathrm{bpm}$, respiratory rate of 32 times/minute, and body temperature of $38.9^{\circ} \mathrm{C}$. Neurological examination revealed a Glasgow Coma Score of 3, round isochoric pupil with normal light reflex, positive nuchal rigidity, negative reflexes of Brudzinski I and II, spastic limbs, increased deep tendon reflexes, positive pathological reflexes and a muscle strength scale of 1 . Laboratory findings showed a hemoglobin level of $12.3 \mathrm{~g} / \mathrm{dl}$, WBC of $7,000 / \mathrm{ml}$, platelet count $200,000 / \mathrm{ml}$, and ESR of $17 \mathrm{~mm} /$ hour. Serum calcium was $8.5 \mathrm{mg} / \mathrm{dl}$, potassium $3.4 \mathrm{meq} / \mathrm{dl}$, glucose level $138 \mathrm{mg} / \mathrm{dl}$, ureum $33 \mathrm{mg} / \mathrm{dl}$, creatinin $0.5 \mathrm{mg} / \mathrm{dl}$, SGOT 49 U/L, and SGPT 38 U/L. CSF was clear, with normal pressure, negative Nonne/Pandy reaction, no cell; the protein content was $19.8 \mathrm{mg} / \mathrm{dl}$ and glucose level $72 \mathrm{mg} / \mathrm{dl}$. Serologic assay (ELISA) of anti Japanese encephalitis virus IgM in CSF was $172.32 \mathrm{U}$, in acute blood serum was $89.43 \mathrm{U}$, and in convalescent serum was 162.4 U. Anti dengue IgM in CSF was 20.63 U, in acute blood serum was $10.32 \mathrm{U}$ and in convalescent serum was $8.69 \mathrm{U}$.

After three weeks of supportive treatment, he showed improvement. His muscle strength scale increased to 3, but had severe verbal sequelae (aphasia).

From the Department of Child Health, Sam Ratulangi, Medical School, Manado Hospital (NM) and the Division of Zoonosis, Directorate of Infectious Disease Control, Ministry of Health, Indonesia (HSW, WC)

Reprint requests to: Nurhayati Masloman, MD, Department of Child Health, Medical School, Sam Ratulangi Universitty, Manado Hospital, Manado, Indonesia. Tel. 62-431-53191, Fax. 62-431-859091. 


\section{Case 2}

A 4 year and 1 month old girl was admitted to Manado Hospital on December 19, 2002, with unconsciousness and fever as chief complaints. One day before admission, she looked sleepy and unresponsive to usual stimuli. Remittent fever was noticed since four days before admission without any seizure, vomiting or headache. Afterwards, diarrhea developed for two days. There was also a pigpen next to her house. Her physical examination revealed a normal nutritional status, blood pressure of $90 / 60 \mathrm{mmHg}$, pulse of $100 \mathrm{bpm}$, respiratory rate of 32 times/minute, and a body temperature of $38.5^{\circ} \mathrm{C}$. Neurologic examination revealed a GCS of 8 , round isochoric pupil with normal light reflex, positive nuchal rigidity, negative reflexes of Brudzinski I and II, spastic limbs, increased deep tendon reflexes, positive pathological reflexes and a muscle strength scale of 5 . Laboratory results were as follows: hemoglobin level $10.9 \mathrm{~g} / \mathrm{dl}$, WBC count $10,800 / \mathrm{ml}$, platelet count 327,000/ ml, ESR $15 \mathrm{~mm} /$ hour, calcium $8.8 \mathrm{mg} / \mathrm{dl}$, potassium $3.9 \mathrm{meq} / \mathrm{dl}$, glucose $110 \mathrm{mg} / \mathrm{dl}$, ureum $30 \mathrm{mg} /$ $\mathrm{dl}$, creatinin $0.5 \mathrm{mg} / \mathrm{dl}$, SGOT $29 \mathrm{U} / \mathrm{L}$, and SGPT 36 U/L. CSF was clear, with normal pressure, negative Nonne/Pandy reaction, no cell, protein was $18.6 \mathrm{mg} / \mathrm{dl}$ and glucose was $59 \mathrm{mg} / \mathrm{dl}$. Serologic assay (ELISA) of anti Japanese encephalitis virus IgM in CSF was 89.95 $\mathrm{U}$, in acute blood serum was $58.75 \mathrm{U}$ and in convalescent serum was $74.28 \mathrm{U}$. Anti dengue IgM in CSF was $0.9 \mathrm{U}$, in acute blood serum was $0.18 \mathrm{U}$ and in convalescent serum was $6.7 \mathrm{U}$.

After 12 days of supportive treatment, she showed improvement. Her fever faded and she regained consciousness on the second day, but she also had verbal sequelae (dysphasia).

\section{Discussion}

The diagnosis of Japanese encephalitis is established by the serologic assay of anti Japanese encephalitis IgM and anti dengue IgM in CSF, acute and convalescent blood sera. Positive value is labeled if anti Japanese encephalitis virus IgM was found $>40 \mathrm{U}$ by ELISA, and if the ratio of anti Japanese encephalitis IgM to anti dengue IgM was $\geq 1$; or the titer of anti Japanese encephalitis IgM in CSF was $>40 \mathrm{U}$ in a single specimen. ${ }^{1,2}$
The level of antibody titer may vary between geographic areas. The antibody titer in Kalimantan is lower than that in Bali. This condition may be caused by the fewer number of natural hosts (i.e. pigs) in Kalimantan than in Bali, since the majority of population in Kalimantan is Moslem who do not consume pork. ${ }^{4}$ On the contrary, Christianity is the major religion in Manado. They are used to consuming pork and own pigpens next to their houses, like both of our patients. These findings were similar to the study of Kari. ${ }^{6}$ He reported that most of his patients (85\%) had pigpens next to their homes.

Both patients were under 15 years old. The incidence rate of Japanese encephalitis in Northern Thailand is approximately 40:100,000 in the population of 5-25 year olds, and decreased next to zero in the age of $>35$ years. ${ }^{7}$ The peak incidence in Northern Vietnam is at the age of $2-7$ years $(83.6 \%)$. Kari reported that the peak incidence of Japanese encephalitis in Bali was at 4 months to 6 years old $(74 \%) .{ }^{6}$

Both patients presented unconsciousness and fever on admission. The first patient was more severely affected (comatose) than the second one (soporous). Other complaints were seizure in the first patient and diarrhea in the second one, but none complained of vomiting or headache.

The manifestations of Japanese encephalitis vary from abortive, acute, sub acute, or gradual. There are three stages of Japenese encephalitis, which are the prodromal, encephalitis, and convalescent stages. In the prodromal stage, symptoms are not specific, such as high fever, nausea, vomiting, malaise, and diarrhea. It can progress on days three to five to encephalitis stage with marked CNS involvement such as seizure, unconsciousness, muscle cramps, nuchal rigidity, and abnormal movements. ${ }^{7,8}$ The seizure is tonic-clonic which occurs in $85 \%$ of cases in children but only $10 \%$ in adults. Some cases are similar to aseptic meningitis. Multiple seizures, prolonged seizure, or status epilepticus are associated with a poor prognosis. ${ }^{9}$ Approximately $30 \%$ of cases show consciousness alteration and upper motor neuron disorder. It is not uncommon that the only symptom is flaccid paralysis. An upper limb paralysis happens more often than that of the lower limb, and is usually asymmetrical. The third stage is convalescent.

The mortality rate of Japanese encephalitis is about 30\%. Most survivors usually develop serious 
sequelae. Up to $50 \%$ show motor deficits i.e., muscle weakness, extrapyramidal symptoms and cerebellar alterations, 20\% show signs of cognitive and severe verbal sequelae; the other $20 \%$ of patients may experience recurrent seizures. Sequelae is more common in children than in adults. ${ }^{1}$

Both of our patients survived, but had sequelae. The first case developed tetraparesis and aphasia, whilst the second developed dysphasia.

Complete blood count and routine CSF examinations of both patients were within normal limits. In general, the diagnostic marker for Japanese encephalitis is leukocytosis, with a CSF showing increased pressure, moderate pleiocytosis $(10-100$ cells/ ml) with predominant lymphocytes, slightly increased protein level (50-200 mg\%), and normal glucose level.

The management of Japanese encephalitis is mainly supportive and symptomatic to control seizures and prevent increased intracranial pressure. There is no specific antiviral therapy for Japanese encephalitis. Corticosteroids have been used empirically, but some double-blind placebo-controlled trials fail to demonstrate any benefit. ${ }^{7,8}$

\section{References}

1. Gobler DJ, Rochrig JT. Arboviruses (Togaviridae and Flaviviridae). In: Collier L, Ballows A, Sussman M, eds. Topley and Wilson's microbiology and microbial Infection. $9^{\text {th }}$ ed. London: Arnold Publisher, 1998. p. 576-600.

2. Solomon T, Nguyen MD, Kneen R, Gainsborough M, Vaughn DW, Vo TK. Japanese encephalitis. J Neurol Neurosurg Psychiatry 2000;68:405-15.

3. Vaughn DW, Hoke CH. The epidemiology of Japanese encephalitis: prospects for prevention. Epidemiol Rev 1992;14:197-221.

4. Wuryadi S, Suroso T. Japanese encephalitis in Indonesia. Southeast Asian J Trop Med Public Health 1989;20:575-80.

5. Suroso T. Japanese encephalitis. Jakarta: Depkes RI Dirjen P3M 1983; p. 1-29.

6. Kari IK, Gautama K, Liu W, Zhi YX. Japanese encephalitis di Bali. In: Naskah Lengkap PKB IKA V-FK Unud/ RSU Sanglah; 2003 Jul 25-26; Bali, Indonesia. Denpasar: FK Unud/RSU Sanglah; 2003.

7. Tiroumourougane SV, Raghava P, Srinivasan S. Japanese viral encephalitis. Postgrad Med J 2002;78:205-15.

8. Solomon T. Recent advances in Japanese encephalitis. J Neurovirol 2003;9(2):274-83.

9. Pouprasert B. Japanese encephalitis in children in Northern Thailand. Southeast Asian J Trop Med Public Health 1989;20:599-603.

10. Huy BU, Tu HC, Wan TU. Early mental and neurological sequelae after Japanese encephalitis: one-year follow-up study in Thailand. Southeast Asian J Trop Med Public Health 1994;15:549-53. 